\title{
BIOECONOMY AS AN ECONOMIC AREA INFLUENCING THE ECONOMIC BALANCE OF INTERNATIONAL TRADE IN POLAND
}

\author{
Chrystian FIRLEJ \\ University of Agriculture in Krakow, Faculty of Agriculture and Economics, Krakow; c.firlej@urk.edu.pl, \\ ORCID: 0000-0001-7724-5717
}

Purpose: The main aim of the article is to characterize the concept of the bioeconomy from the theoretical point of view and to present its impact on the economic balance of international trade in Poland in 2008-2017. SWOT analysis of the bioeconomy in Poland was presented as an additional aim of the paper.

Design/methodology/approach: The annual reports published by the Central Statistical Office in Poland were used to assess the impact of the bioeconomy on the results of international trade in Poland.

Findings: Based on the analysis, it was found that all areas of the Polish bioeconomy have a positive impact on the level of Polish imports and exports. In the analyzed period the balance of foreign trade has significantly improved, despite the fact that employment in this area has decreased.

Practical implications: Bioeconomy and its areas as a factor positively influencing the development of the whole country should be further developed and skillfully managed while maintaining appropriate means of financing its activities.

Originality/value The article emphasizes the importance of the issue of the bioeconomy and outlines the directions of considerations for further analysis of the studied sector.

Keywords: bioeconomy, development factors, innovation, international trade.

Category of the paper: General review, research paper.

\section{Introduction}

Today's challenges and problems that the world is facing today make the bioeconomy a major area and a driver of change and innovation in the world and Europe in the coming years. Such challenges include changes in food production and industry, ensuring food security, reducing the level of exploitation of natural resources and minimizing the impact on climate change. The bioeconomy is considered to be a strategic activity that affects the economic 
development of all sectors and industries that are responsible for the production, processing and use of biological resources. Biological resources are transformed into high value-added products such as food, feed, bio-products and bioenergy (Czernyszewicz, 2016).

The "Europe 2020" strategy adopted in March 2010 by the European Commission places particular emphasis on the development of the bioeconomy, which includes the production potential of areas of agriculture, forestry, fisheries with aquaculture and coastal economy, renewable energy production (biomass and biotechnology). This area of the EU economy is becoming an indispensable strategy for sustainable economic growth of the whole European Union (Commission communication..., 2012).

The work has an analytical and focused character, which has allowed to focus on the real dimension of the renewable raw materials-based economy while taking into account primary production - referred to as the "old bioeconomy" and aspects of the knowledge-based bioeconomy - referred to as the "new bioeconomy" - the Knowledge Biobased Bioeconomy (Baer-Nawrocka, 2010). The paper covers research on the problems of the bioeconomy in the light of economic results achieved by the European Union and Poland in the field of the bioeconomy and selected areas of the economy. The analysis was carried out using data from the Central Statistical Office in Poland (GUS), the European Statistical Office (EUROSTAT), the Organisation for Economic Cooperation and Development (OECD) and the European Commission. In addition to the analysis of statistical data, the paper uses studies of the subject literature, which consists of scientific articles published in domestic and foreign journals, numerous scientific studies and monographs.

The main aim of the study is to present the bioeconomy from the theoretical point of view and to what extent the bioeconomy affects the level of employment in the bioeconomy sector and its specific areas, added value, turnover value and the achieved results of imports, exports and the balance of turnover in the Polish bioeconomy in 2008-2017. In addition, the factors of development of the bioeconomy in Poland were presented, a SWOT analysis of the Polish bioeconomy was performed and prospects for the future of the Polish bioeconomy were presented.

\section{The conceptual apparatus of the bioeconomy}

Already in 1977, Nicolas Georgescu-Roegen pointed out the biological limits of growth in the study of economic phenomena. According to Georgescu-Roegen, in the process of analyzing economic processes, it is necessary to understand the biophysical and social context of production, exchange and consumption processes. For the new approach he proposed the name bioeconomics (Georgescu-Roegen, 1977). In the literature on bioeconomy and in strategic documents of various national and international organizations there is no uniform definition of 
the bioeconomy. The problem with the unambiguous definition of the term "bioeconomy" is related to the twofold approach to its scope (Ratajczak, 2013):

- resource-based (production based on biological resources),

- process based (use of biotechnology).

It was not until the 1990s that the term "bioeconomy" was first defined by two geneticists J.E. Cabot and R. Martinez, who in 1998 defined the bioeconomy as: an economic activity based on research and implementation focusing on the understanding of mechanisms and processes at the molecular (genetic) level to be implemented and applied in industrial processes that will lead to changes in the global economy and provide the basis for a new sector (Martinez, 1998). Another definition of the bioeconomy is that proposed by the Government Department for Environment, Food and Rural Affairs (DEFRA), which defines this area of the economy as an economic activity that captures the hidden value of biological and renewable resources, resulting in better health, growth and environmentally friendly development (Maciejczak, and Hofreiter, 2013). The Organisation for Economic Cooperation and Development (OECD), in turn, highlights the potential of biotechnology by supporting it with research carried out in the EU Member States (Frascati Manual, 2002). The definition of a bioeconomy proposed by the OECD defines it as an activity that uses biotechnology, bioprocesses and bioproducts to produce specific goods and services (The bioeconomy, 2009). According to the OECD, the bioeconomy includes an area where biotechnology has a significant impact on the country's economic growth. This depends on factors such as (Philp, 2015):

- applying advanced knowledge in the field of genes and cellular processes to develop new products,

- using renewable biomass for sustainable production,

- integration of biotechnological knowledge in multisectoral applications.

In the United States, the bioeconomy has been identified as a priority area to provide great potential for growth and offer great social benefit. According to the U.S. administration, the bioeconomy will improve the health and life expectancy of Americans, eliminate dependence on fossil fuels, change production processes, diversify agriculture, provide new jobs and increase productivity (National Bioeconomy Blueprint, 2012). The White House, in documents published in 2012, defines the bioeconomy as an area based on applying research and innovation in life sciences to fuel economic activity and generate public profits (Pink, and Wojnarowska, 2020). The most comprehensive definition of the bioeconomy was proposed by the European Commission (Directorate General for Science), which covers the social and environmental implications of the bioeconomy. The European Commission defines the bioeconomy as: an economy based on biological resources originating from land and sea and waste, including waste from food production, used in industry and for energy production. The term also includes bio-processes implemented for green industries (European Commission, 2012a). In 2018, the strategy for the bioeconomy in Europe was complemented by further 
actions aimed at strengthening the relationship between the economy, the environment and society. The A Sustainable Bioeconomy for Europe: Strengthening the Connection between the Economy, Society and Environment document emphasizes the interdisciplinary nature of the bioeconomy (Pink, and Wojnarowska, 2020).

The concept of the bioeconomy in various scientific publications is also often referred to as: bio-based economy, biobased economy or Knowledge Bio-Based Economy and is understood as an economy that relies on materials, chemical products and energy that are produced from biological resources (McCormick, 2010). As can be seen when reviewing the literature, there are different approaches to understanding and defining the area of the bioeconomy and the concept itself. Their scope depends on the goals, expectations, values and problems faced by the authors. Undoubtedly, the bioeconomy is one of the answers to the aforementioned challenges and problems of the modern world (Pink, and Wojnarowska, 2020). The economic aspect of the bioeconomy and the areas of the bioeconomy and biobusiness directly refer to the theory of economics. Economics as a science, its scope also deals with the study of the phenomenon of resource limitation and its allocation in agribusiness and biobusiness. Lummin Horlings and Terry Marsden describe the multi-faceted dimension of bioeconomics as a set of economic activities that use biological processes and renewable resources and have a positive impact on the sustainability of the economy (Horlings, and Marsden, 2011). Figure 1 shows the pyramid of biobusiness knowledge (Urban, 2014).

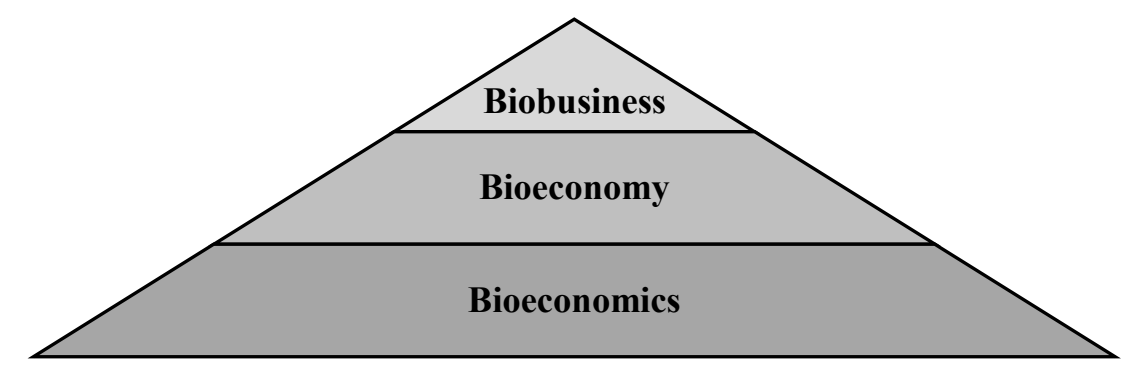

Figure 1. Pyramid of biobusiness knowledge. Source: Urban S., 2014, Agribusiness and Biobusiness. Theory and practice, Wrocław University of Economics, Wrocław, p. 243.

The reality of economic life directly affects the theoretical and analytical aspects of the bioeconomy concept. At the same time, the new economic concept of the bioeconomy is not a new practical concept because it was already the dominant economic sector in pre-industrial times. At that time, it was largely represented by agriculture, fishing, forestry and the processing of biological raw materials. Nowadays, the bioeconomy covers not only these natural sectors, but also the areas of processing, industrial production, transport, marketing and consumption, at the same time implying scientific research and innovation. Bioeconomy with its scope and activities includes the "chain of processing and value creation" consisting of mixing products from primary biomass production sectors (by means of processing and distribution sectors) to final users e.g. as food, biomaterials, bioproducts for consumption (Gołębiewski, 2013). A properly constructed system for creating and using knowledge and innovations integrates 
three elements of the bioeconomy: biomass production, processing and production, distribution and consumption. Figure 2 shows a simplified scheme of a real bioeconomy system in the European Union (BECOTEPS, 2010).
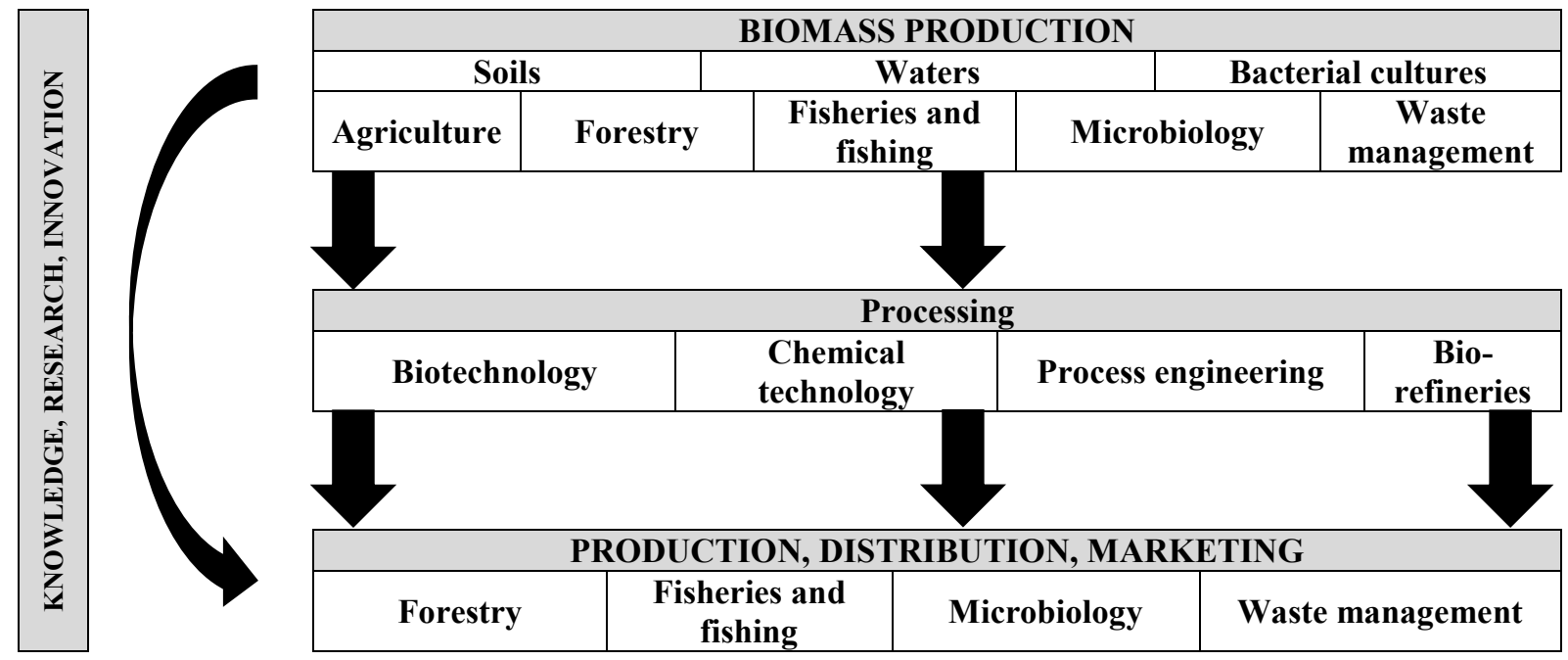

Figure 2. Elements of the bioeconomy system in the European Union. Source: BECOTEPS (2010). Bioeconomy innovation, Bioeconomy Council Report, 2010.

As can be seen in the presented diagram, the basis of the bioeconomy is the production of biomass, which is considered to be a renewable resource and its main application is the production of bio-products, food and biofuels and feeds. Processing of biomass into more valuable and complex products takes place through the application of biotechnology, chemical technologies and physical processes (Adamowicz, 2017).

\section{Factors influencing the development of the bioeconomy}

The area of the bioeconomy is conditioned by many factors influencing its functioning and development, which is inextricably linked to the application of an innovative approach consisting in the creation of new patterns of effective use of human capital. The potential of human resources, infrastructure and funding opportunities should generate the development of new products and production techniques. Moreover, this potential should affect the synergy of the implemented scientific, scientific-technical, innovation and economic and social policies. Thanks to such cooperation of the above mentioned areas there will be a possibility of more effective production of basic raw materials, semi-finished products and in industries which use biological resources for production. Figure 3 shows the factors of bioeconomy development that indicate that the implementation of research and its implementation in the area of the bioeconomy can effectively support or block its further proper development (Chyłek and Rzepecka, 2011). 


\begin{tabular}{|c|c|c|c|}
\hline $\begin{array}{c}\text { Sustainable biological } \\
\text { resources }\end{array}$ & Human capital & Science and research & $\begin{array}{c}\text { Availability of innovative } \\
\text { solutions }\end{array}$ \\
\hline Finance and fiscal system & \multicolumn{2}{|c|}{ BIOECONOMY } & Legal status \\
\hline $\begin{array}{c}\text { Coherence of scientific } \\
\text { and economic policies }\end{array}$ & $\begin{array}{c}\text { Information and } \\
\text { modern } \\
\text { communication }\end{array}$ & Consultancy & Infrasture \\
\hline
\end{tabular}

Figure 3. Factors influencing the development of the bioeconomy. Source: Chyłek E.K., Rzepecka M., 2011, Bioeconomy - competitiveness and sustainable use of resources, "Polish Journal of Agronomy" No. 7, Puławy, p. 8.

Eugeniusz Chyłek and Monika Rzepecka (2011) consider biological resources, human capital and the legal status of the country as the most important factors influencing the development of the bioeconomy. According to the authors, the indicated factors are important in the process of research and activities in the area of the bioeconomy. Moreover, an important factor is the fiscal system, which significantly affects the availability of solutions resulting from science and research. It can be predicted that the legal status and rules of financing the bioeconomy and research in its area will require changes in the nearest future. In the process of bioeconomy development it is very important to improve cooperation in science, business and public and private administration. The effectiveness of bioeconomy development is influenced by the principles of implemented policies, especially the coherence of scientific and economic policies.

\section{SWOT analysis of the bioeconomy area in Poland}

The horizontal nature of the state's scientific, innovation and scientific-technical policy related to the development of the bioeconomy in Poland, as well as any actions taken in its scope, should be preceded and formulated on the basis of thorough analyses - also of the internal and external environment. Already at the stage of initial assumptions related to the undertaken activities should take into account the specific conditions and factors affecting the development of each sector forming the bioeconomy. The modern structure of management and financing of science shapes the policy of the Polish bioeconomy, which may encounter some difficulties related to its development. This is illustrated by the SWOT analysis presented in Table 1, which compares the strengths and weaknesses of the Polish bioeconomy with its opportunities and threats from the external environment. The sooner the Polish bioeconomy removes its unfavorable conditions, the greater the chance for its further development and implementation of the assumed strategic objectives (Chyłek, and Rzepecka, 2011). 
Table 1.

SWOT analysis of the Polish bioeconomy and the process of shaping its program

\begin{tabular}{|c|c|}
\hline Strengths & Weaknesses \\
\hline $\begin{array}{l}\text { - skilled workers } \\
\text { - diversified and purposeful research } \\
\text { - innovative research actors }\end{array}$ & $\begin{array}{l}\text { - low spending on research and development } \\
\text { - insufficient financial resources for "high risk" } \\
\text { projects } \\
\text { - inadequate division of competences and } \\
\text { responsibilities in terms of substantive supervision } \\
\text { and research funding } \\
\text { - fragmentation of biotechnological innovation in } \\
\text { traditional sectors } \\
\text { - lack of initiatives and professional structures for } \\
\text { knowledge transfer }\end{array}$ \\
\hline Opportunities & $\begin{array}{l}\text { Threats } \\
\end{array}$ \\
\hline $\begin{array}{l}\text { - preservation of the natural resource base } \\
\text { - increase of the importance of sustainable } \\
\text { development in the production sector } \\
\text { - increase in demand for sustainable production of } \\
\text { biofuels } \\
\text { - changes in agriculture, small trade, industry and the } \\
\text { service sector } \\
\text { - increase in research and development spending } \\
\text { - increased demand for renewable raw material } \\
\text { resources for industries and for material and energy } \\
\text { use }\end{array}$ & $\begin{array}{l}\text { - withholding changes necessary to introduce in such } \\
\text { systems as: fiscal, financial, legal, administrative and } \\
\text { organizational } \\
\text { - too slow technological transfer } \\
\text { - the objectives of the projects are determined mainly } \\
\text { by the scientific community, to a lesser extent they } \\
\text { result from the external needs of business entities } \\
\text { - insufficient transdisciplinary approach to new } \\
\text { solutions }\end{array}$ \\
\hline
\end{tabular}

Source: Chyłek E.K., Rzepecka M., 2011, Bioeconomy - competitiveness and sustainable use of resources, "Polish Journal of Agronomy" No. 7, Puławy, p. 8.

It should be stressed that the above mentioned SWOT analysis factors for the development of the Polish bioeconomy are only selected ones, as the number of stimulants and destimulants for the development of this sector is definitely higher and depends on the specific industry and area of the bioeconomy.

\section{Research material and methodology}

The subject of conducted analysis was the assessment of the impact of the bioeconomy on the economic results of the European Union and Poland in the years 2008-2017. The rationale for choosing such a form of research was the multiplicity of the bioeconomy area and its impact on the economic results such as: the level of employment in the bioeconomy sector, including its specific areas, the added value of the bioeconomy and its areas, the value of the turnover of the bioeconomy, the results of imports, exports and the balance of turnover in the Polish bioeconomy, which was achieved by the European Union and Poland in the indicated years. For the purpose of the publication an analysis was carried out to indicate which areas of the bioeconomy achieved the best results in particular years, and which areas achieved worse results compared to previous years. The research was conducted using reports published by the 
European Commission, the Central Statistical Office in Poland, the European Statistical Office (EUROSTAT) and the Organisation for Economic Cooperation and Development (OECD).

The countries belonging to the European Union are facing ecological and economic challenges, which forces them to take the concept of future generations' development into account. The main challenge for the countries forming the Community is to achieve a sustainable bioeconomy and independence from fossil fuels and to achieve a situation where agriculture will ensure food security and biomass as a renewable raw material for industry. The great progress and development in natural sciences has made the bioeconomy one of the fastest growing and providing a significant number of jobs in various sectors of the European economy. Table 2 presents employment in the bioeconomy sector in the countries belonging to the European Union between 2008-2017.

Table 2.

Bioeconomy potential of European Union countries in 2008-2017

\begin{tabular}{|c|c|c|c|c|c|c|c|c|c|c|}
\hline Specification & 2008 & 2009 & 2010 & 2011 & 2012 & 2013 & 2014 & 2015 & 2016 & 2017 \\
\hline Total number & \multicolumn{10}{|c|}{ in millions } \\
\hline $\begin{array}{l}\text { of people } \\
\text { employed in the } \\
\text { bioeconomy }\end{array}$ & 21.2 & 20.36 & 20.19 & 19.77 & 19.53 & 19.12 & 19.09 & 18.73 & 18.53 & 18.64 \\
\hline $\begin{array}{l}\text { Number of } \\
\text { people } \\
\text { employed in the } \\
\text { area of: }\end{array}$ & \multicolumn{10}{|c|}{ in millions } \\
\hline agriculture & 11.72 & 11.43 & 11.31 & 10.93 & 10.81 & 10.51 & 10.44 & 10.1 & 9.67 & 9.65 \\
\hline forestry & 0.514 & 0.506 & 0.49 & 0.512 & 0.534 & 0.524 & 0.535 & 0.538 & 0.533 & 0.548 \\
\hline $\begin{array}{c}\text { fisheries and } \\
\text { aquaculture } \\
\end{array}$ & 0.196 & 0.186 & 0.183 & 0.176 & 0.175 & 0.180 & 0.180 & 0.178 & 0.182 & 0.181 \\
\hline $\begin{array}{r}\text { food, beverages } \\
\text { and tobacco } \\
\end{array}$ & 4.74 & 4.55 & 4.64 & 4.6 & 4.57 & 4.55 & 4.57 & 4.55 & 4.77 & 4.86 \\
\hline biotextiles & 1.06 & 0.91 & 0.847 & 0.834 & 0.793 & 0.766 & 0.749 & 0.731 & 0.727 & 0.718 \\
\hline $\begin{array}{l}\text { wood products } \\
\text { and furniture }\end{array}$ & 1.84 & 1.68 & 1.64 & 1.61 & 1.55 & 1.49 & 1.51 & 1.52 & 1.54 & 1.53 \\
\hline $\begin{array}{r}\text { paper } \\
\text { production }\end{array}$ & 0.682 & 0.647 & 0.641 & 0.648 & 0.642 & 0.632 & 0.634 & 0.637 & 0.643 & 0.658 \\
\hline $\begin{array}{l}\text { chemicals of } \\
\text { biological origin }\end{array}$ & 0.424 & 0.415 & 0.402 & 0.414 & 0.410 & 0.418 & 0.419 & 0.428 & 0.425 & 0.444 \\
\hline liquid biofuels & 0.025 & 0.027 & 0.028 & 0.031 & 0.027 & 0.027 & 0.025 & 0.024 & 0.025 & 0.024 \\
\hline biofuels & 0.007 & 0.009 & 0.010 & 0.017 & 0.020 & 0.022 & 0.024 & 0.025 & 0.025 & 0.026 \\
\hline
\end{tabular}

Source: own study based on: https://ec.europa.eu/knowledge4policy/bioeconomy/topic/economy_en (access: 07.07.2020)

Table 3 presents the added value of the bioeconomy in the European Union between 2008-2017. 
Table 3.

Added value of the bioeconomy in the European Union between 2008-2017

\begin{tabular}{|c|c|c|c|c|c|c|c|c|c|c|}
\hline \multirow{3}{*}{$\begin{array}{l}\text { Specification } \\
\text { Total added } \\
\text { value of the } \\
\text { bioeconomy in } \\
\text { the European } \\
\text { Union }\end{array}$} & 2008 & 2009 & 2010 & 2011 & 2012 & 2013 & 2014 & 2015 & 2016 & 2017 \\
\hline & \multicolumn{10}{|c|}{ in billion EUR } \\
\hline & 573 & 529 & 567 & 591 & 587 & 597 & 613 & 632 & 640 & 685 \\
\hline $\begin{array}{l}\text { Added value of } \\
\text { the bioeconomy } \\
\text { in the } \\
\text { European } \\
\text { Union in: }\end{array}$ & \multicolumn{10}{|c|}{ in billion EUR } \\
\hline agriculture & 170 & 149 & 165 & 176 & 177 & 184 & 184 & 183 & 181 & 203 \\
\hline forestry & 21 & 18 & 19 & 23 & 22 & 23 & 25 & 26 & 25 & 26 \\
\hline $\begin{array}{c}\text { fisheries and } \\
\text { aquaculture }\end{array}$ & 6 & 6 & 6 & 7 & 6 & 6 & 7 & 7 & 7 & 7 \\
\hline $\begin{array}{r}\text { food, beverages } \\
\text { and tobacco }\end{array}$ & 206 & 203 & 212 & 215 & 214 & 219 & 226 & 237 & 243 & 252 \\
\hline biotextiles & 23 & 19 & 21 & 22 & 21 & 21 & 21 & 21 & 22 & 22 \\
\hline $\begin{array}{l}\text { wood products } \\
\text { and furniture }\end{array}$ & 52 & 44 & 47 & 46 & 45 & 44 & 47 & 50 & 51 & 53 \\
\hline $\begin{array}{r}\text { paper } \\
\text { production }\end{array}$ & 39 & 36 & 39 & 42 & 42 & 41 & 43 & 45 & 46 & 48 \\
\hline $\begin{array}{r}\text { chemicals of } \\
\text { biological } \\
\text { origin }\end{array}$ & 51 & 50 & 52 & 53 & 52 & 51 & 54 & 56 & 57 & 65 \\
\hline liquid biofuels & 2 & 2 & 3 & 3 & 3 & 3 & 3 & 3 & 3 & 4 \\
\hline biofuels & 2 & 2 & 2 & 4 & 4 & 4 & 4 & 5 & 5 & 5 \\
\hline
\end{tabular}

Source: own study based on: https://ec.europa.eu/knowledge4policy/bioeconomy/topic/economy_en (access: 07.07.2020)

Table 4 presents the turnover of the bioeconomy in the European Union in the years 2008-2017.

Table 4.

Bioeconomy turnover in the European Union in 2008-2017

\begin{tabular}{|c|c|c|c|c|c|c|c|c|c|c|}
\hline \multirow{3}{*}{$\begin{array}{l}\text { Specification } \\
\text { Total turnover } \\
\text { of the } \\
\text { bioeconomy in } \\
\text { the European } \\
\text { Union } \\
\end{array}$} & 2008 & 2009 & 2010 & 2011 & 2012 & 2013 & 2014 & 2015 & 2016 & 2017 \\
\hline & \multicolumn{10}{|c|}{ in billion EUR } \\
\hline & 2,115 & 1,928 & 2,027 & 2,178 & 2,212 & 2,254 & 2,278 & 2,323 & 2,310 & 2,454 \\
\hline $\begin{array}{l}\text { Turnover of the } \\
\text { bioeconomy in } \\
\text { the European } \\
\text { Union in: }\end{array}$ & \multicolumn{10}{|c|}{ in billion EUR } \\
\hline agriculture & 402 & 360 & 384 & 419 & 428 & 442 & 436 & 436 & 426 & 450 \\
\hline forestry & 42 & 36 & 41 & 48 & 46 & 47 & 49 & 50 & 49 & 51 \\
\hline $\begin{array}{c}\text { fisheries and } \\
\text { aquaculture }\end{array}$ & 13 & 12 & 13 & 14 & 14 & 14 & 15 & 15 & 15 & 15 \\
\hline $\begin{array}{r}\text { food, beverages } \\
\text { and tobacco }\end{array}$ & 1,040 & 973 & 1,004 & 1,067 & 1,109 & 1,132 & 1,145 & 1,159 & 1,155 & 1,242 \\
\hline biotextiles & 90 & 74 & 78 & 84 & 79 & 79 & 80 & 80 & 79 & 80 \\
\hline $\begin{array}{r}\text { wood products } \\
\text { and furniture }\end{array}$ & 187 & 157 & 166 & 172 & 169 & 165 & 174 & 182 & 184 & 188 \\
\hline
\end{tabular}


Cont. table 4.

\begin{tabular}{|r|c|c|c|c|c|c|c|c|c|c|}
\hline $\begin{array}{r}\text { paper } \\
\text { production }\end{array}$ & 166 & 147 & 162 & 177 & 173 & 178 & 180 & 185 & 188 & 196 \\
\hline $\begin{array}{r}\text { chemicals of } \\
\text { biological origin }\end{array}$ & 158 & 151 & 159 & 168 & 163 & 166 & 168 & 186 & 184 & 198 \\
\hline liquid biofuels & 11 & 10 & 13 & 16 & 15 & 15 & 14 & 13 & 13 & 14 \\
\hline biofuels & 6 & 6 & 7 & 12 & 15 & 15 & 16 & 15 & 14 & 19 \\
\hline
\end{tabular}

Source: own study based on: https://ec.europa.eu/knowledge4policy/bioeconomy/topic/economy_en (access: 07.07.2020).

Nowadays it is not easy to present the bioeconomy sector and its importance in the structure of the Polish economy, which is due to its complexity and the fact that it is made up of different sections and divisions of the national economy. One of the basic and at the same time the most important measures determining the importance of the bioeconomy in Poland is its share in employment and foreign trade. The basic raw material sectors of the bioeconomy in Poland are: agriculture, forestry, fisheries and aquaculture, food, beverages and tobacco, biotextiles, chemicals of biological origin, liquid biofuels, wood and furniture products, paper and wood production. The number of persons employed in these sectors of the bioeconomy and the overall level of employment in the area of the bioeconomy in Poland in 2008-2017 is presented in Table 5.

Table 5.

Number of persons employed in the area of the bioeconomy in Poland between 2008-2017

\begin{tabular}{|c|c|c|c|c|c|c|c|c|c|c|}
\hline \multirow{3}{*}{$\begin{array}{l}\text { Specification } \\
\text { Total } \\
\text { number of } \\
\text { persons } \\
\text { employed in } \\
\text { the } \\
\text { bioeconomy }\end{array}$} & 2008 & 2009 & 2010 & 2011 & 2012 & 2013 & 2014 & 2015 & 2016 & 2017 \\
\hline & \multicolumn{10}{|c|}{ number of persons } \\
\hline & $\begin{array}{c}3,049 \\
494\end{array}$ & $\begin{array}{c}2,922 \\
250\end{array}$ & $\begin{array}{c}2,815 \\
143\end{array}$ & $\begin{array}{c}2,787 \\
133\end{array}$ & $\begin{array}{c}2,724 \\
659\end{array}$ & $\begin{array}{c}2,611 \\
142\end{array}$ & $\begin{array}{c}2,601 \\
632\end{array}$ & $\begin{array}{c}2,636 \\
106\end{array}$ & $\begin{array}{c}2,524 \\
439\end{array}$ & $\begin{array}{c}2,492 \\
153\end{array}$ \\
\hline $\begin{array}{l}\text { Number of } \\
\text { persons } \\
\text { employed in } \\
\text { the area of: }\end{array}$ & \multicolumn{10}{|c|}{ number of persons } \\
\hline agriculture & $\begin{array}{c}2,128 \\
100\end{array}$ & $\begin{array}{c}2,033 \\
400\end{array}$ & $\begin{array}{c}1,934, \\
300\end{array}$ & $\begin{array}{c}1,921 \\
900\end{array}$ & $\begin{array}{c}1,865 \\
200\end{array}$ & $\begin{array}{c}1,772 \\
100\end{array}$ & $\begin{array}{c}1,721 \\
300\end{array}$ & $\begin{array}{c}1,762 \\
900\end{array}$ & $\begin{array}{c}1,615 \\
000\end{array}$ & $\begin{array}{c}1,562, \\
400\end{array}$ \\
\hline forestry & 62,000 & 56,700 & 64,900 & 68,800 & 73,900 & 71,900 & 76,700 & 71,500 & 76,700 & 87,700 \\
\hline $\begin{array}{c}\text { fisheries and } \\
\text { aquaculture }\end{array}$ & 6,300 & 5,300 & 4,700 & 4,000 & 6,800 & 8,700 & 6,300 & 7,500 & 9,300 & 9,800 \\
\hline $\begin{array}{r}\text { food, } \\
\text { beverages } \\
\text { and tobacco } \\
\end{array}$ & $\begin{array}{c}445,33 \\
7 \\
\end{array}$ & $\begin{array}{c}436,44 \\
8\end{array}$ & $\begin{array}{c}430,09 \\
0 \\
\end{array}$ & $\begin{array}{c}419,83 \\
2\end{array}$ & $\begin{array}{c}422,24 \\
6 \\
\end{array}$ & $\begin{array}{c}410,31 \\
6\end{array}$ & $\begin{array}{c}418,43 \\
0\end{array}$ & $\begin{array}{c}423,19 \\
7\end{array}$ & $\begin{array}{c}428,85 \\
2\end{array}$ & $\begin{array}{c}434,19 \\
6\end{array}$ \\
\hline biotextiles & 97,293 & 83,041 & 75,502 & 70,883 & 65,103 & 59,509 & 59,990 & 59,441 & 60,126 & 59,515 \\
\hline $\begin{array}{r}\begin{array}{r}\text { chemicals of } \\
\text { biological } \\
\text { origin }\end{array} \\
\end{array}$ & 22,291 & 22,451 & 22,330 & 21,448 & 20,942 & 20,412 & 20,982 & 21,604 & 22,009 & 21,698 \\
\hline $\begin{array}{r}\text { liquid } \\
\text { biofuels }\end{array}$ & 2,545 & 3,008 & 2,494 & 3,415 & 4,947 & 4,747 & 4,737 & 4,880 & 4,908 & 2,948 \\
\hline biofuels & 693 & 1,033 & 1,687 & 1,914 & 2,479 & 1,929 & 2,247 & 2,021 & 1,627 & 1,327 \\
\hline $\begin{array}{r}\text { wood } \\
\text { products and } \\
\text { furniture * }\end{array}$ & . & . & . & . & . & . & . & . & . & . \\
\hline $\begin{array}{r}\text { paper } \\
\text { production * }\end{array}$ & & . & . & . & . & . & . & . & . & . \\
\hline
\end{tabular}

Source: own study based on: https://ec.europa.eu/knowledge4policy/visualisation/bioeconomydifferent-countries_en (access: 07.07.2020). 
Table 6 presents the total turnover of the Polish bioeconomy and its individual sectors in 2008-2017.

Table 6.

Polish bioeconomy turnover in 2008-2017

\begin{tabular}{|c|c|c|c|c|c|c|c|c|c|c|}
\hline \multirow{3}{*}{$\begin{array}{l}\text { Specification } \\
\text { Total } \\
\text { turnover of } \\
\text { the Polish } \\
\text { bioeconomy }\end{array}$} & 2008 & 2009 & 2010 & 2011 & 2012 & 2013 & 2014 & 2015 & 2016 & 2017 \\
\hline & \multicolumn{10}{|c|}{ in million EUR } \\
\hline & $\begin{array}{c}103,37 \\
6\end{array}$ & 86,698 & 95,782 & $\begin{array}{c}105,91 \\
8\end{array}$ & $\begin{array}{c}111,40 \\
0\end{array}$ & $\begin{array}{c}114,31 \\
3\end{array}$ & $\begin{array}{c}116,82 \\
9\end{array}$ & $\begin{array}{c}117,18 \\
7\end{array}$ & $\begin{array}{c}117,93 \\
8\end{array}$ & $\begin{array}{c}130,43 \\
0\end{array}$ \\
\hline $\begin{array}{l}\text { The value of } \\
\text { turnover of } \\
\text { the Polish } \\
\text { bioeconomy } \\
\text { in: }\end{array}$ & \multicolumn{10}{|c|}{ in million EUR } \\
\hline agriculture & 24,175 & 19,312 & 21,902 & 25,611 & 25,939 & 26,763 & 26,556 & 24,491 & 24,513 & 28,265 \\
\hline forestry & 2,388 & 1,882 & 2,227 & 2,654 & 2,612 & 2,677 & 2,867 & 2,959 & 2,950 & 3,315 \\
\hline $\begin{array}{l}\text { fisheries and } \\
\text { aquaculture }\end{array}$ & 112 & 103 & 131 & 123 & 131 & 149 & 149 & 142 & 166 & 153 \\
\hline $\begin{array}{r}\text { food, } \\
\text { beverages } \\
\text { and tobacco }\end{array}$ & 52,584 & 44,824 & 48,419 & 52,547 & 56,903 & 58,025 & 58,239 & 58,512 & 59,206 & 65,661 \\
\hline biotextiles & 2,348 & 1,740 & 1,856 & 1,986 & 1,952 & 1,942 & 2,082 & 2,172 & 2,252 & 2,356 \\
\hline $\begin{array}{r}\text { chemicals of } \\
\text { biological } \\
\text { origin }\end{array}$ & 2,891 & 2,685 & 3,312 & 3,056 & 3,173 & 3,279 & 3,396 & 3,592 & 3,487 & 3,586 \\
\hline $\begin{array}{r}\text { liquid } \\
\text { biofuels }\end{array}$ & 401 & 379 & 406 & 605 & 1,038 & 735 & 905 & 1045 & 1059 & 769 \\
\hline biofuels & 180 & 278 & 344 & 427 & 579 & 444 & 549 & 519 & 371 & 312 \\
\hline $\begin{array}{r}\text { wood } \\
\text { products and } \\
\text { furniture * } \\
\end{array}$ & & $\cdot$ & $\cdot$ & . & . & 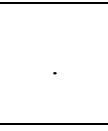 & & . & . & . \\
\hline $\begin{array}{r}\text { paper } \\
\text { production * }\end{array}$ & & $\cdot$ & $\cdot$ & . & . & & & . & . & . \\
\hline
\end{tabular}

* no data available

Source: own study based on: https://ec.europa.eu/knowledge4policy/visualisation/bioeconomydifferent-countries_en (access: 07.07.2020).

Table 7 presents the added value in the Polish bioeconomy and its individual sectors in 2008-2017.

Table 7.

Added value of the Polish bioeconomy in 2008-2017

\begin{tabular}{|c|c|c|c|c|c|c|c|c|c|c|}
\hline Specification & 2008 & 2009 & 2010 & 2011 & 2012 & 2013 & 2014 & 2015 & 2016 & 2017 \\
\hline Total added & \multicolumn{10}{|c|}{ in million EUR } \\
\hline $\begin{array}{l}\text { bioeconomy in } \\
\text { Poland }\end{array}$ & 26,450 & 23,070 & 24,963 & 27,361 & 26,071 & 27,884 & 28,047 & 27,636 & 28,643 & 33,403 \\
\hline $\begin{array}{l}\text { Added value of } \\
\text { the bioeconomy } \\
\text { in Poland in: }\end{array}$ & \multicolumn{10}{|c|}{ in million EUR } \\
\hline agriculture & 8,216 & 6,968 & 8,188 & 9,383 & 9,154 & 10,082 & 9,337 & 8,064 & 8,665 & 11,331 \\
\hline forestry & 1,023 & 865 & 1,040 & 1,333 & 1,160 & 1,205 & 1,343 & 1,328 & 1,397 & 1,447 \\
\hline $\begin{array}{l}\text { fisheries and } \\
\text { aquaculture }\end{array}$ & 47 & 47 & 56 & 52 & 60 & 58 & 61 & 80 & 93 & 85 \\
\hline
\end{tabular}


Cont. table 7.

\begin{tabular}{|r|c|c|c|c|c|c|c|c|c|c|}
\hline $\begin{array}{r}\text { food, beverages } \\
\text { and tobacco }\end{array}$ & 10,070 & 9,147 & 9,191 & 9,807 & 9,332 & 9,498 & 9,768 & 10,291 & 10,475 & 12,202 \\
\hline $\begin{array}{r}\text { biotextiles } \\
\text { chemicals of } \\
\text { biological } \\
\text { origin }\end{array}$ & 882 & 638 & 674 & 666 & 589 & 614 & 664 & 673 & 693 & 718 \\
\hline liquid biofuels & 87 & 71 & 75 & 122 & 151 & 161 & 150 & 153 & 167 & 90 \\
\hline $\begin{array}{r}\text { biofuels } \\
\text { wood products } \\
\text { and furniture * }\end{array}$ & 62 & 115 & 155 & 193 & 261 & 194 & 244 & 237 & 156 & 139 \\
\hline $\begin{array}{r}\text { paper } \\
\text { production * }\end{array}$ &. & $\cdot$ &. &. &. &. &. &. &. &. \\
\hline
\end{tabular}

* no data available

Source: own study based on: https://ec.europa.eu/knowledge4policy/visualisation/bioeconomydifferent-countries_en (access: 07.07.2020).

A special role in the Polish bioeconomy sector is played by the processing industry - mainly the food industry. A great importance is attached to the results of foreign trade turnover (export/import) of products coming from this sector, such as: food products, live animals and products of animal origin, products of plant origin and fats and oils. Table 8 presents statistical data on import, export and foreign trade of these bioeconomy sectors in the years 2008-2017.

Table 8.

Results of imports, exports and balance of turnover in the Polish bioeconomy in 2008-2017

\begin{tabular}{|c|c|c|c|c|c|c|c|c|c|c|}
\hline \multirow{2}{*}{ Specification } & 2008 & 2009 & 2010 & 2011 & 2012 & 2013 & 2014 & 2015 & 2016 & 2017 \\
\hline & \multicolumn{10}{|c|}{ in million PLN } \\
\hline \multirow{2}{*}{ Import } & 497,02 & 463,38 & 536,22 & 62,337 & 648,12 & 656,09 & 704,56 & 740,97 & 786,47 & 880,07 \\
\hline & 8.3 & 2.6 & 0.6 & 2.7 & 7.6 & 8.2 & 7.5 & 3.3 & 0.1 & 8.4 \\
\hline \multicolumn{11}{|l|}{ including: } \\
\hline $\begin{array}{l}\text { Food } \\
\text { preparations }\end{array}$ & $\begin{array}{c}13,936 . \\
4\end{array}$ & $\begin{array}{l}16,559 . \\
2\end{array}$ & $\begin{array}{c}18,141 . \\
5\end{array}$ & $\begin{array}{l}20,684 . \\
5\end{array}$ & $\begin{array}{c}23,225 . \\
0\end{array}$ & $\begin{array}{c}23,688 . \\
8\end{array}$ & $\begin{array}{c}25,589 . \\
6\end{array}$ & $\begin{array}{l}28,150 . \\
2\end{array}$ & $\begin{array}{c}30,183 . \\
1\end{array}$ & $\begin{array}{c}32,931 . \\
9\end{array}$ \\
\hline $\begin{array}{l}\text { Live animals } \\
\text { and products } \\
\text { of animal } \\
\text { origin }\end{array}$ & $8,827.0$ & $\begin{array}{c}11,035 . \\
3\end{array}$ & $\begin{array}{c}11,856 . \\
0\end{array}$ & $\begin{array}{c}13,469 . \\
0\end{array}$ & $\begin{array}{l}15,296 . \\
2\end{array}$ & $\begin{array}{c}18,026 . \\
3\end{array}$ & $\begin{array}{c}18,963 . \\
6\end{array}$ & $\begin{array}{c}18,890 . \\
8\end{array}$ & $\begin{array}{c}22,237 . \\
4\end{array}$ & $\begin{array}{c}24,007 . \\
4\end{array}$ \\
\hline $\begin{array}{l}\text { Products of } \\
\text { plant origin }\end{array}$ & $\begin{array}{c}11,161 . \\
2\end{array}$ & $\begin{array}{c}10,738 . \\
9\end{array}$ & $\begin{array}{c}11,647 . \\
0\end{array}$ & $\begin{array}{c}14,352 . \\
9\end{array}$ & $\begin{array}{c}14,998 . \\
8\end{array}$ & $\begin{array}{c}14,885 . \\
6\end{array}$ & $\begin{array}{c}15,610 . \\
8\end{array}$ & $\begin{array}{c}17,105 . \\
7\end{array}$ & $\begin{array}{c}19,120 . \\
8\end{array}$ & $\begin{array}{c}21,259 . \\
5\end{array}$ \\
\hline Fats and oils & $2,005.2$ & $1,760.7$ & $2,002.0$ & $3,145.5$ & $3,491.4$ & $3,203.0$ & $3,149.7$ & $3,068.8$ & $3,629.2$ & $4,163.4$ \\
\hline \multirow{2}{*}{ Specification } & 2008 & 2009 & 2010 & 2011 & 2012 & 2013 & 2014 & 2015 & 2016 & 2017 \\
\hline & \multicolumn{10}{|c|}{ in million PLN } \\
\hline Export & $\begin{array}{c}40,538 \\
3.1\end{array}$ & $\begin{array}{c}42,324 \\
2.0\end{array}$ & $\begin{array}{c}481,05 \\
8.2 \\
\end{array}$ & $\begin{array}{c}558,73 \\
9.0\end{array}$ & $\begin{array}{c}603,41 \\
8.6 \\
\end{array}$ & $\begin{array}{c}647,87 \\
8.8 \\
\end{array}$ & $\begin{array}{c}693,47 \\
1.6 \\
\end{array}$ & $\begin{array}{c}750,83 \\
5.8 \\
\end{array}$ & $\begin{array}{c}803,47 \\
7.8 \\
\end{array}$ & $\begin{array}{c}882,61 \\
9.5\end{array}$ \\
\hline \multicolumn{11}{|l|}{ including: } \\
\hline $\begin{array}{l}\text { Food } \\
\text { preparations }\end{array}$ & $\begin{array}{c}1,8023 . \\
7\end{array}$ & $\begin{array}{c}22,728 . \\
7\end{array}$ & $\begin{array}{c}24,854 . \\
4\end{array}$ & $\begin{array}{c}28,892 . \\
7\end{array}$ & $\begin{array}{c}34,069 . \\
3\end{array}$ & $\begin{array}{c}38,003 . \\
1\end{array}$ & $\begin{array}{c}41,994 . \\
0\end{array}$ & $\begin{array}{c}46,998 . \\
0\end{array}$ & $\begin{array}{c}51,023 . \\
4\end{array}$ & $\begin{array}{l}59,285 . \\
2\end{array}$ \\
\hline $\begin{array}{l}\text { Live animals } \\
\text { and products } \\
\text { of animal } \\
\text { origin }\end{array}$ & $\begin{array}{c}1,4239 . \\
9\end{array}$ & $\begin{array}{c}15,666 . \\
8\end{array}$ & $\begin{array}{c}18,033 . \\
1\end{array}$ & $\begin{array}{c}21,239 . \\
0\end{array}$ & $\begin{array}{c}24,523 . \\
3\end{array}$ & $\begin{array}{c}27,768 . \\
3\end{array}$ & $\begin{array}{l}29,115 . \\
6\end{array}$ & $\begin{array}{c}30,491 . \\
7\end{array}$ & $\begin{array}{c}32,832 . \\
4\end{array}$ & $\begin{array}{c}38,670 . \\
7\end{array}$ \\
\hline $\begin{array}{l}\text { Products of } \\
\text { plant origin }\end{array}$ & $7,498.2$ & $\begin{array}{c}10,116 . \\
0\end{array}$ & $9,803.6$ & $\begin{array}{c}1,0754 . \\
3\end{array}$ & $\begin{array}{c}14,854 . \\
1\end{array}$ & $\begin{array}{c}17,288 \\
9\end{array}$ & $\begin{array}{c}17,976 . \\
8\end{array}$ & $\begin{array}{c}19,808 . \\
8\end{array}$ & $\begin{array}{c}19,222 . \\
6\end{array}$ & $\begin{array}{c}18,922 . \\
2\end{array}$ \\
\hline Fats and oils & $1,061.1$ & $1,105.1$ & $1,288.6$ & $1,528.4$ & $1,728.8$ & $2,342.7$ & $2,422.2$ & $2,567.2$ & $2,703.3$ & $1,869.1$ \\
\hline
\end{tabular}


Cont. table 8 .

\begin{tabular}{|c|c|c|c|c|c|c|c|c|c|c|}
\hline \multirow{2}{*}{ Specification } & 2008 & 2009 & 2010 & 2011 & 2012 & 2013 & 2014 & 2015 & 2016 & 2017 \\
\hline & \multicolumn{10}{|c|}{ in million PLN } \\
\hline $\begin{array}{l}\text { Turnover } \\
\text { balance }\end{array}$ & $\begin{array}{c}- \\
9,1645 . \\
2\end{array}$ & $\begin{array}{c}- \\
4,0140 . \\
6\end{array}$ & $\begin{array}{c}- \\
5,5162 . \\
4\end{array}$ & $\begin{array}{c}- \\
6,4633 . \\
7 \\
\end{array}$ & $\begin{array}{c}- \\
4,4709 . \\
0\end{array}$ & $\begin{array}{c}- \\
8,219.4\end{array}$ & $\begin{array}{c}- \\
1,1095 . \\
9\end{array}$ & $9,862.5$ & $\begin{array}{c}1,7007 . \\
7\end{array}$ & $2,541.1$ \\
\hline
\end{tabular}

Source: own study based on CSO reports - Statistical Yearbook of Agriculture in 2008-2017.

Figure 4 presents the trend line and dynamics of Polish import and export results in 2008-2017 (in billion PLN).
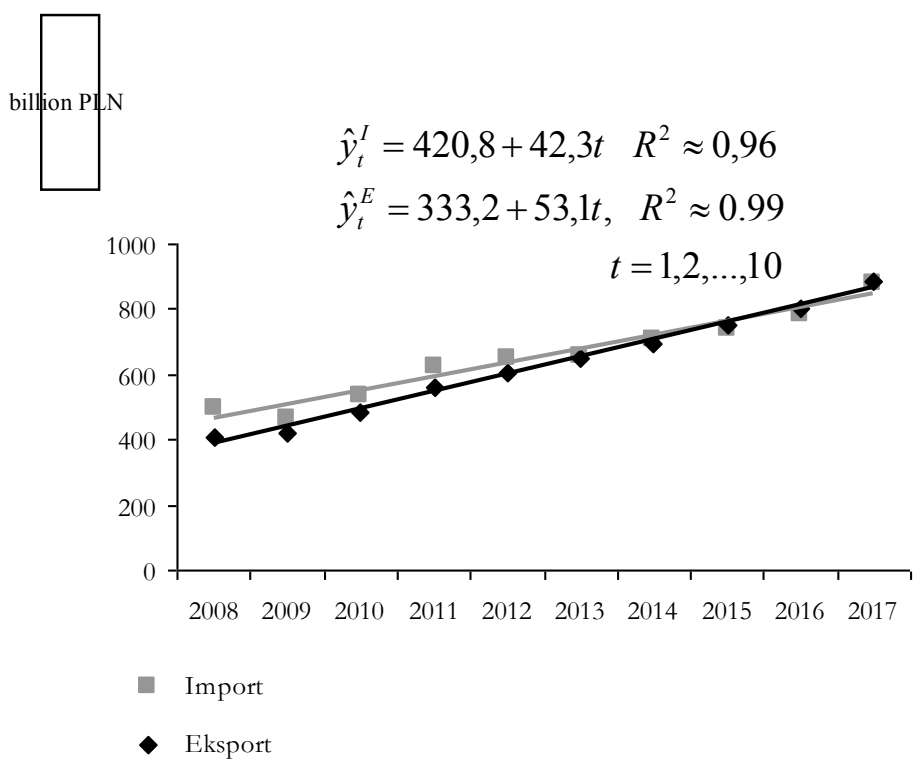

\begin{tabular}{ccccc}
\multirow{2}{*}{ Year } & \multicolumn{2}{c}{ Import } & \multicolumn{2}{c}{ Export } \\
\cline { 2 - 5 } & growth & index & growth & index \\
\hline 2009 & -33.65 & 0.93 & 17.86 & 1.04
\end{tabular}

$\begin{array}{lllll}2010 & 72.84 & 1.16 & 57.82 & 1.14\end{array}$

$\begin{array}{lllll}2011 & 87.15 & 1.16 & 77.68 & 1.16\end{array}$

$\begin{array}{lllll}2012 & 24.75 & 1.04 & 44.68 & 1.08\end{array}$

$\begin{array}{lllll}2013 & 7.97 & 1.01 & 44.46 & 1.07\end{array}$

$\begin{array}{lllll}2014 & 48.47 & 1.07 & 45.59 & 1.07\end{array}$

$\begin{array}{lllll}2015 & 36.41 & 1.05 & 57.36 & 1.08\end{array}$

$\begin{array}{lllll}2016 & 45.50 & 1.06 & 52.64 & 1.07\end{array}$

$\begin{array}{lllll}2017 & 93.61 & 1.12 & 79.14 & 1.10\end{array}$

Figure 4. Import and export result dynamics in the Polish bioeconomy in 2008-2017 (in billion PLN) with adjusted trend line. Source: own study based on Table 8 .

In addition, Table 9 presents the balance of turnover in the Polish bioeconomy in the years 2008-2017 (in billion PLN).

Table 9.

Balance of turnover in the Polish bioeconomy between 2008-2017 (in billion PLN)

\begin{tabular}{|c|c|c|c|c|c|}
\hline \multirow{2}{*}{ Year } & \multirow{2}{*}{ Total } & \multicolumn{4}{|c|}{ including } \\
\cline { 3 - 6 } & & $\begin{array}{c}\text { food } \\
\text { preparations }\end{array}$ & $\begin{array}{c}\text { live animals and products } \\
\text { of animal origin }\end{array}$ & products of plant origin & $\begin{array}{c}\text { fats and } \\
\text { oils }\end{array}$ \\
\hline 2008 & -91.65 & 4.09 & 5.41 & -3.66 & -0.94 \\
\hline 2009 & -40.14 & 6.17 & 4.63 & -0.62 & -0.66 \\
\hline 2010 & -55.16 & 6.71 & 6.18 & -1.84 & -0.71 \\
\hline 2011 & -64.63 & 8.21 & 7.77 & -3.60 & -1.62 \\
\hline 2012 & -44.71 & 10.84 & 9.23 & -0.14 & -1.76 \\
\hline 2013 & -8.22 & 14.31 & 9.74 & 2.40 & -0.86 \\
\hline 2014 & -11.10 & 16.40 & 10.15 & 2.37 & -0.73 \\
\hline
\end{tabular}


Cont. table 9 .

\begin{tabular}{|l|c|c|c|c|c|}
\hline 2015 & 9.86 & 18.85 & 11.60 & 2.70 & -0.50 \\
\hline 2016 & 17.01 & 20.84 & 10.60 & 0.10 & -0.93 \\
\hline 2017 & 2.54 & 26.35 & 14.66 & -2.34 & -2.29 \\
\hline
\end{tabular}

Source: own study based on Table 8 .

\section{Results and discussion}

The total employment in the bioeconomy sector in the European Union decreased from 21.2 million in 2008 to 18.64 million of persons employed in the bioeconomy in 2017 . This represents a $12.1 \%$ decrease in employment in the analyzed period. The total number of persons employed in the bioeconomy sector in Poland in the years 2008-2017 also decreased by 557341 persons in 2017 (2.5 million) compared to 2008 (3.05 million), which is a decrease of $18.28 \%$ in the analyzed period. The areas of the bioeconomy where employment increased in 2017 compared to 2008 in the European Union were: forestry, food, beverages and tobacco, chemicals of biological origin and the area of biofuels. The areas where employment decreased were: agriculture, fisheries and aquaculture, biotextiles, wood products and furniture, paper production, liquid biofuels. The added value of the bioeconomy in the European Union between 2008 and 2017 is much better in the analysis. In 2017 the total added value in the European Union increased from EUR 573 billion in 2008 to EUR 685 billion, which is an increase of $19.54 \%$. In the case of the added value of individual areas of the bioeconomy in the European Union, the value reduction occurred only in the area of biotextiles (from 23 billion in 2008 to 22 billion in 2017). In the other analyzed areas there was an increase in added value.

A similar situation occurred in the case of the bioeconomy's turnover in the European Union. The total turnover of the bioeconomy increased by EUR 0.339 billion during the period under review, an increase of $16.02 \%$ in 2017. (EUR 2.454 billion) compared to 2008 . (EUR 2.115 billion). Again, the decline in turnover occurred only in the area of biological textiles and amounted to EUR 10 billion (11.12\%) between 2008 (EUR 90 billion) and 2017 (EUR 80 billion).

Analyzing the importance and development of individual sectors of the Polish bioeconomy, it is important to emphasize the large growth in employment in such areas as: forestry $(41.45 \%$ increase), fisheries and aquaculture (55.55\% increase), liquid biofuels (15.83\% increase) and biofuels $(91.48 \%$ increase) in the analyzed period. The areas where employment decreased were: agriculture, food, beverages and tobacco, biotextiles, chemicals of biological origin.

In the mentioned years, the results of turnover in the Polish bioeconomy in general and in all individual sectors of the bioeconomy were very good. The total turnover volume between 2008 and 2017 increased from EUR 103,376 million in 2008 to EUR 130,430 million in 2017, 
which represents an increase of $26.17 \%$. As far as the added value of the Polish bioeconomy in the period 2008-2017 is concerned, only two sectors recorded a lower value in 2017 compared to 2008 . These were biotextiles and chemicals of biological origin. The total added value during the period was positive and reached EUR 33,403 million in 2017 (2008 = EUR 26,450 million). The increase of EUR 6,953 million was $26.28 \%$. For the Polish sectors: wood products and furniture and paper production, no official data were provided.

An important feature of the Polish foreign trade is achieving better and better results in the years under review, both in the case of import and export. The value of the Polish bioeconomy's import in 2017 reached PLN 880,078.4 million, which is an increase of PLN 383,050.1 million compared to 2008, when it reached PLN 497,028.2 million. A similar situation occurred in the case of Polish export in the area of the bioeconomy. In 2017 the value of export amounted to PLN 882,619.5 million, which is an increase of PLN 477,236.4 million compared to 2008 (PLN 405,383.1 million). Positive results were also achieved in individual areas of the Polish bioeconomy. Table 10 presents a comparison of results achieved in 2017 with 2008 in particular areas of the bioeconomy and the dynamics of changes in their value.

Table 10.

Import and export results of particular sectors forming the Polish bioeconomy in 2008 and 2017

\begin{tabular}{|r|c|c|c|c|}
\hline Specification & Value in 2008 (A) & Value in 2017 (B) & Change (B-A) & $\begin{array}{c}\text { Dynamics } \\
\mathbf{2 0 0 8}=\mathbf{1 0 0}\end{array}$ \\
\hline Import, including: & \multicolumn{4}{|c|}{236.30} \\
\hline $\begin{array}{r}\text { Food preparations } \\
\text { Live animals and } \\
\text { products of animal origin }\end{array}$ & $13,936.4$ & $32,931.9$ & $18,995.5$ & $2,721.92$ \\
\hline Products of plant origin & 882.0 & $24,007.4$ & $23,125.4$ & 190.47 \\
\hline Fats and oils & $11,161.2$ & $21,259.5$ & $10,098.3$ & 207.63 \\
\hline Export, including: & $2,005.2$ & $4,163.4$ & $2,158.2$ & 328.92 \\
\hline Food preparations & $18,023.7$ & $59,285.2$ & $41,261.5$ & 271.56 \\
\hline $\begin{array}{r}\text { Live animals and } \\
\text { products of animal origin }\end{array}$ & $14,239.9$ & $38,670.7$ & $24,430.8$ & 252.35 \\
\hline Products of plant origin & $7,498.2$ & $18,922.2$ & 11,424 & 176.14 \\
\hline Fats and oils & $1,061.1$ & $1,869.1$ & 808 & \\
\hline
\end{tabular}

Source: own study based on Table 8 in million PLN.

As it can be observed, the growth dynamics in each of these areas is positive and the highest score in the area of the import in 2017 compared to 2008 was achieved in the area of "live animals and products of animal origin" and was over $2700 \%$. In case of export, the highest growth rate in 2017 was almost $329 \%$ in the area of "food preparations". 


\section{Summary}

For the proper development of the bioeconomy in the European Union, it is necessary to increase the amount of funding for research and development and to increase the importance of knowledge and innovation in the development of entrepreneurship, while taking into account the needs of consumers and increasing market opportunities. Moreover, it is very important for various entities to cooperate in order to implement pro-innovative policies in the functioning of the bioeconomy. Such actions require close cooperation between public administration employees, universities and entrepreneurs. The big challenge for the bioeconomy is the estimated growth of the world population over the next 30 years by more than $30 \%$ (from 7 billion in 2012 to more than 9 billion in 2050) (European Commission, 2012).

Nowadays, the great interest and importance of the bioeconomy is confirmed by the constantly growing number of books and scientific articles containing such terms as: bioeconomy, bio-economy, bio-based economy, biobased economy, especially in titles, abstracts, and keywords (Staffas, and Gustavsson, and McCormick, 2013).

The analysis of the results of Polish import and export and their steady growth presented in the paper may prove the growing importance of the bioeconomy in the whole economic system of Poland. Despite performing a partial analysis of the bioeconomy, this area should be constantly researched and analyzed as a whole using the concept of sustainable development. The bioeconomy as a "new type" of economy must simultaneously solve environmental problems and provide bio-products such as food, feed, fibers and fuels. This requires a new organization of the economy and financing of biotechnological research together with the design and production of market products.

\section{References}

1. Adamowicz, M. (2017). Biogospodarka - koncepcja, zastosowanie i perspektywy. Warszawa: Zagadnienia Ekonomiki Rolnej, 1(350), p. 41.

2. Baer-Nawrocka, A., Markiewicz, N. (2010). Zróżnicowanie przestrzenne potencjału produkcyjnego $w$ rolnictwie $w$ krajach UE. Roczniki Nauk Rolniczych, Seria G, T. 97, Z. 4. Warszawa, p. 13.

3. BECOTEPS (2010). Bioeconomy innovation. Bioeconomy Council Report.

4. Chyłek, E.K., Rzepecka, M. (2011). Biogospodarka - konkurencyjność i zrównoważone wykorzystanie zasobów. Polish Journal of Agronomy, $n r$ 7. Puławy, p. 8.

5. Czernyszewicz, E. (2016). Uwarunkowania i perspektywy rozwoju biogospodarki w Unii Europejskiej. Zeszyty Naukowe Szkoły Głównej Gospodarstwa Wiejskiego w Warszawie, Problemy Rolnictwa Światowego, t. 16 (XXXI), z. 3, Warszawa, p. 49. 
6. European Commission (2012). 'Innovating for Sustainable Growth: A Bioeconomy for Europe', Communication from the Commission to the European Parliament, the Council. Brussels: The European Economic and Social Committee and the Committee of the Regions.

7. Frascati Manual (2002). OECD, p. 27, 187.

8. Georgescu-Roegen, N. (1977). Inequality, limits and growth from a bioeconomic viewpoint. Review of Social Economy, Vol. 35, No. 3, pp. 361-375.

9. Gołębiewski, J. (2013). Zrównoważona biogospodarka - potencjat i czynniki rozwoju. Warszawa: IX Kongres Ekonomistów Polskich, pp. 6-7.

10. Horlings, I., Marsden, T. (2011). Towards sustainable spatial development? Exploring the implications of the emerging bio-economy in agri-food and regional Innovation. Sociologias, no. 13, p. 27.

11. Komisja Europejska (2012). Bio-economy Newsletter, February. http://ec.europa.eu/ research/bioeconomy/press/pdf/120202_research_en.pdf, 12.08.2020.

12. Komunikat Komisji do Parlamentu Europejskiego (2012). Innowacje $w$ stużbie zrównoważonego wzrostu: biogospodarka dla Europy. Bruksela: Rady Europejskiego Komitetu Ekonomiczno-Społecznego oraz Komitetu Regionów COM (2012)60 final, 13.02.2012, p. 3 .

13. Maciejczak, M., Hofreiter, K. (2013). How to define bioeconomy? Roczniki Naukowe Stowarzyszenia Ekonomistów Rolnictwa i Agrobiznesu, t. XV, z. 4, Warszawa, pp. 245-246.

14. Martinez, J. (1998). Genomies and the World's Economy. Science Magazine, vol. 281(5379).

15. McCormick, K. (2010). The Knowlegde-Based Bio-Economy in Europe, p. 5. http://lup.lub.lu.se/record/1774406, 25.08.2020.

16. National Bioeconomy Blueprint (2012). Whitehall. Washington, pp. 1-12, www.ascesionpublishing.com, 01.08.2020.

17. Philp, J. (2015). Green growth and bioeconomy from an international perspective. Paris: OECD, p. 1, www.james.philp@oecd.org, 5.08.2020.

18. Pink, M., Wojnarowska, M. (2020). Biogospodarka - wybrane aspekty. Warszawa: Difin, pp. 29-30.

19. Ratajczak, E. (2013). Rolnictwo i leśnictwo w świetle koncepcji biogospodarki. Warszawa: IX Kongres Ekonomistów Polskich, p. 1, www.pte.pl./kongres/referaty, 12.08.2020.

20. Staffas, L., Gustavsson, M., McCormick, K. (2013). Strategies and Policies for the Bioeconomy and Bio-Based Economy: An Analysis of Official National Approaches. Sustainability, No. 5, pp. 2751-2769.

21. The bioeconomy to 2030 (2009). Designing a Policy Agenda.

22. Urban, S. (2014). Agrobiznes i biobiznes. Teoria i praktyka. Wrocław: Uniwersytet Ekonomiczny we Wrocławiu, p. 243. 